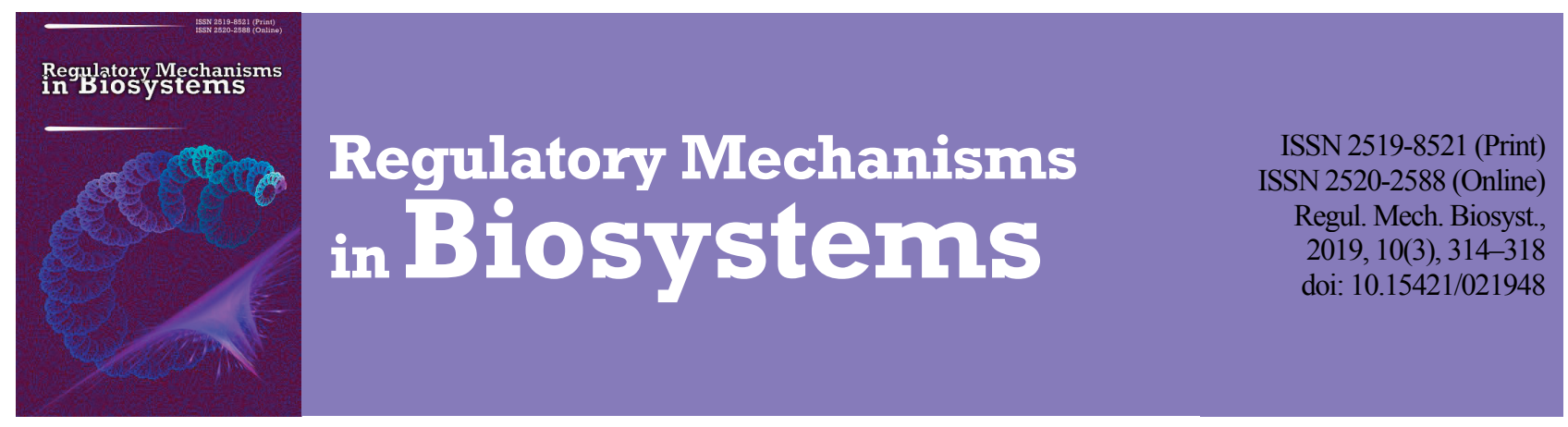

\title{
Influence of staphylococcal Phage SAvB14 on biofilms, formed by Staphylococcus aureus variant bovis
}

\author{
Y. V. Horiuk*, M. D. Kukhtyn**, Y. S. Stravskyy**, S. I. Klymnyuk**, K. M. Vergeles***, V. V. Horiuk* \\ *State Agrarian and Engineering University in Podilya, Kamianets-Podilskyi, Ukraine \\ **I. Y. Horbachevsky Ternopil State Medical University, Ternopil, Ukraine \\ ***National Pirogov Memorial Medical University, Vinnytsya, Ukraine
}

Article info

Received 28.07.2019

Received in revised form 21.08.2019

Accepted 22.08.2019

State Agrarian and Engineering

University in Podilya,

Shevchenko st., 13

Kamianets-Podilskyi,

32300, Ukraine

Tel.: +38-097-661-79-64.

E-mail:goruky@ukr.net

I. Horbachevsky Ternopil State Medical University, Maidan Voli, 1 ,

Ternopil, 46001, Ukraine

Tel.: +38-097-239-20-57.

E-mail:kuchtynnic@gmail.com

National Pirogov Memorial Medical University,

Danylo Halytskyi st., 58a,

Vinnytsya, 21036, Ukrain

Tel.: +38-067-299-59-96.

E-mail:kvergeles@gmail.com

\begin{abstract}
Horiuk, Y. V., Kukhtyn, M. D., Stravskyy, Y. S., Klymnyuk, S. I., Vergeles, K. M., \& Horiuk, V. V. (2019). Influence of staphylococcal Phage SAvB14 on biofilms, formed by Staphylococcus aureus variant bovis. Regulatory Mechanisms in Biosystems, 10(3), 314-318. doi:10.15421/021948

The use of bacteriophages for the treatment of chronic inflammatory processes has proved to be relevant, especially during isolation of antibiotic-resistant pathogens formed in biofilms. The article presents the results of research on the influence of Phage SAvB14 on young and mature biofilms formed by Staphylococcus aureus variant bovis. In the experiments we used cultures of $S$. aureus and a specific Phage SAvB14 isolated from the secretion of the mammary gland of cows suffering from chronic mastitis. In the study of the influence of bacteriophage on formed biofilms we determined the optical density of the dye solution that was washed from the biofilm photometrically on a spectrophotometer PE-5400UV (Ecroskhim, Russia) and the number of staphylococcal cells in the biofilm after the action of the bacteriophage on 24-hour and 72-hour biofilms by a ten-fold dilution on beef-extract agar. It was determined that under the influence of the bacteriophage on young 24-hour biofilms of $S$. aureus var. bovis, the optical density of the dye solution from biofilm increased within 4 hours up to $10 \%$ and the number of microbial cells increased by 1.8 times. After 32 hours of bacteriophage action, the optical density of the dye solution decreased on average by $34 \%$ compared to the initial density and the number of $S$. aureus cells in the biofilm decreased by 30 times. This indicates that microbial cells of young biofilms are not subject to complete lysis during the action of even this specific bacteriophage. Degradation of $77.5 \%$ of biofilm under the influence of the bacteriophage was observed on mature 72-hour biofilm within 32 hours at $37^{\circ} \mathrm{C}$. At the same time, viable cells of $S$. aureus were not isolated from the biofilm. This indicates the high lytic activity of the bacteriophage against mature biofilm bacteria and the possibility of its use in chronic staphylococcal infections caused by S. aureus var. bovis. Thus, the obtained data indicate that when mature 72-hour biofilms are exposed to the researched bacteriophage, their degradation is more intense compared with the young 24-hour biofilms, and the amount of destroyed biofilm was on average 2 times higher. This suggests that the use of specific staphylococcal Phage SAvB14 isolated by us for the destruction of biofilm, formed by $S$. aureus var. bovis, is promising.
\end{abstract}

Keywords: phage activity; degradation of biofilm; staphylococci; 24- and 72-hour biofilms.

\section{Introduction}

Currently, there are many definitions of biofilm, but generally, it is considered as agglomerations of microbial cells and substances they produce that are attached to inert surfaces (Donlan, 2009; Kukhtyn et al., 2017; Felipe et al., 2019). The structure of biofilm depends on many factors: morphological composition of microorganisms, their physiological state, the physical environment, including turbulent flow conditions and properties of the surface to which the cells are attached (Stewart \& Franklin, 2008).

Biofilm development processes have been studied by many scientists (Morris et al., 2018; Felipe et al., 2019; Zimmerli \& Sendi, 2019), mainly in vitro. Staphylococcus aureus, Escherichia coli and Pseudomonas aeruginosa were mainly used as model microorganisms (Bahamondez-Canas et al., 2018; Iglesias et al., 2019). The ability of S. aureus to form biofilm is considered one of its main strategies for survival when infecting the host and biofilm is considered an important sign of pathogenicity (Horiuk et al., 2019). During the development of chronic infections, such as subclinical mastitis, the formation of biofilm can be an effective way of preserving pathogens in the microenvironment of the mammary gland and transforming the disease into a chronic form.
Biofilm infections are difficult to treat with antimicrobial agents, and the bacterial resistance to antibiotics increases to 1,000-fold level compared with the bacteria observed in planktonic conditions (Horiuk et al., 2018; Siala et al., 2018).

The mechanism of increased resistance of bacteria in biofilm to antibiotics is not fully understood. This process is explained by researchers in different ways. Scientists have found that antibiotic resistance of microorganisms in biofilm is associated with its physical properties (Cabrera et al., 2011). It was found that the environment surrounding the microbial cells contains a number of macromolecular structures, the dominant among which is the exopolysaccharide (EPS) produced by the bacteria. Therefore, the exopolysaccharide matrix of biofilm can restrict the diffusion of antibacterial agents (Bahamondez-Canas et al., 2018). Also, the negatively charged exopolysaccharides of the matrix effectively bind the positively charged antibiotics, preventing their access to target bacteria (Stewart \& Franklin, 2008).

One of reasons for antibiotic resistance of microorganisms in a biofilm is their "ecological variability", as soon as the biofilm is formed, the adhesion between the bacteria becomes stronger. In such condition, the bacterial cell is not susceptible to division, which leads to decrease in proliferation. Then, the bacteria in biofilm gradually lose their direct 
connection with the external environment and, therefore, their metabolism becomes slower, thus reducing the sensitivity to antibiotics (Mah \& O'Toole, 2001; Stewart \& Franklin, 2008; Hurlow et al., 2015). Therefore, alternative therapeutic and prophylactic approaches against microbial infections in biofilm are necessary.

Recently, many scientists have suggested that, for environmental and physiological reasons, bacteriophages are likely to be more effective than antibiotics in the destruction of bacteria in biofilm (Dias et al., 2013; Horiuk, 2018; Milh et al., 2019). The effect of phages on biofilms includes an initial stage of bacterial adsorption, followed by bacterial infection. Infection with phages leads to the death of sensitive bacteria and their lysis. The removal of biofilm bacteria with the help of lysis leads to physiological changes in bacteria in deep layers of biofilms, allowing these bacteria to further infect the phages more effectively (Svircev et al., 2018; Tkhilaishvili et al., 2018).

Many phages produce polysaccharide depolymerases and when phage infection develops, phage enzymes decompose capsular polysaccharides (CPSs), O-polysaccharide chains of lipopolysaccharide (LPS) molecules, or extracellular polysaccharides (EPSs) that form the matrix of biofilm (Latka et al., 2017). This facilitates the penetration of phages into deeper layers of biofilm with subsequent lysis of target bacteria (Parasion et al., 2014). However, at present, researchers are not focussing enough attention on the possibility of using specific bacteriophages isolated from the infection center against a particular disease. This is especially true for such a disease as subclinical mastitis of cows, which causes significant economic losses due to the development of antibiotic resistance in pathogens and the necessity of rejecting milk. Therefore, the development of economically beneficial methods and preparations with the use of specific bacteriophages against the main pathogen $S$. aureus var. bovis is promising and relevant.

The objective of this work was determining the effect of Phage SAvB14 on young and mature biofilms formed by $S$. aureus var. bovis.

\section{Materials and methods}

We studied 8 cultures of $S$. aureus and the specific bacteriophage Phage SAvB14, which we isolated from the secretion of mammary glands of cows suffering from chronic mastitis and placed at the State Scientific Control Institute of Biotechnology and Strains of Microorganisms. In the experiments we used strains of $S$. aureus var. bovis, which were lysed by Phage SAvB14 according to the double-layer agar method (Wills et al., 2005).

Disposable plastic Petri dishes were used to determine the optical density of the formed biofilms. Into each dish, $5 \mathrm{~cm}^{3}$ of beef-extract broth and $1 \mathrm{~cm}^{3}$ of daily culture of $S$. aureus at the concentration of $10^{5} \mathrm{CFU} / \mathrm{cm}^{3}$ were introduced and incubated at $37^{\circ} \mathrm{C}$ for 24 and 72 hours. After incubation, the dishes were cleaned from the planktonic (unbraced) microorganisms by washing three times with phosphate buffer, dried and the formed biofilms were fixated with $96 \%$ of ethyl alcohol during 10 minutes. Then they were stained with $0.1 \%$ solution of crystal violet for 10 minutes. In the Petri dishes, $3.0 \mathrm{~cm}^{3}$ of $96 \%$ of ethyl alcohol were added; the Petri dishes were left for 20-30 minutes, occasionally being shaken. The optical density of alcohol solution was measured spectrophotometrically at the wavelength of $570 \mathrm{nM}$ (Stepanovic et al., 2000).

During the study of the effect of bacteriophage on formed biofilms, the optical density of biofilm, the number of staphylococcal cells in the biofilm and the bacteriophage titre were determined. Determination of the number of staphylococci in biofilm after bacteriophage action was performed on young (24-hour) and mature (72-hour) biofilms grown in plastic Petri dishes. After 24- or 72-hour incubation of cultures, the dishes were washed three times with sterile phosphate buffer to remove the planktonic (unbraced) microorganisms and $5 \mathrm{~cm}^{3}$ of Phage SAvB14 was introduced. During the 32 hours exposure for (every 4 hours), the phage was poured out, the dishes were washed three times with sterile phosphate buffer, $5 \mathrm{~cm}^{3}$ of sterile $0.5 \%$ sodium chloride solution was added and microbial biofilm was carefully washed off the walls and the bottom of the dish using a sterile tampon. From the dishes, $1.0 \mathrm{~cm}^{3}$ of suspension was taken, a number of ten-fold dilutions were prepared, $1.0 \mathrm{~cm}^{3}$ of each dilution was inoculated in a Petri dish, MPA was poured and incubated at $37^{\circ} \mathrm{C}$ for $24-48$ hours to determine the number of staphylococci. Along with the study of the number of staphylococcal cells in the biofilm, every 4 hours rinses were extracted to determine the titre of the phage according to the double-layer agar method (Wills et al., 2005).

Statistical processing of the results was carried out according to methods of variation statistics using the program Statistica 9.0 (StatSoft Inc., USA). Non-parametric methods of research were used (WilcoxonMann-Whitney test). The arithmetic mean (x) and the standard error (SE) were determined. The difference between the comparable values was considered significant at $\mathrm{P}<0.05$.

\section{Results}

Under the influence of bacteriophage on 24-hour biofilms of S. aureus var. bovis, we noted the $10.0 \pm 0.3 \%(\mathrm{P}<0.05)$ growth of the optical density of the dye solution during 12-hour incubation compared with their initial density (Fig. 1)

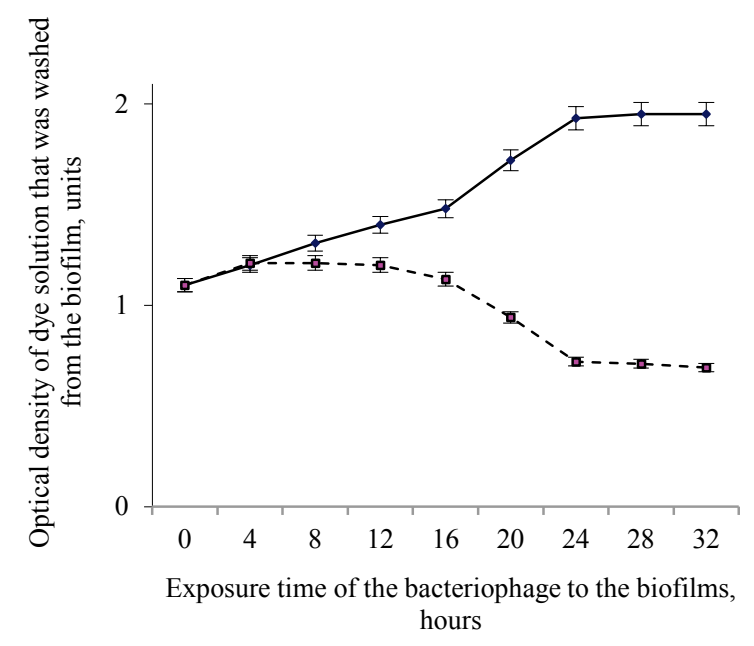

Fig. 1. Influence of bacteriophage on the 24-hour biofilm S. aureus variant bovis: solid line - optical density of dye solution from biofilms without the influence of bacteriophage (control); dashed line - optical

density of dye solution from biofilms under the influence of

bacteriophage (experiment); data are shown as mean $\pm \mathrm{SD}$

During the following incubation hours, a gradual decrease in the optical density of dye from biofilms was observed compared to the initial density. On the 28th hour of contact of the bacteriophage with the biofilm formed by the strain of $S$. aureus var. bovis, the density of the dye decreased by $63.7 \pm 2.4 \%(\mathrm{P}<0.05)$ compared to the biofilm that was not affected by the bacteriophage and by $34.5 \pm 0.7 \%(\mathrm{P}<0.05)$ compared to the initial density. During the following effect of bacteriophage on the biofilm, the optical density of dye solution of the biofilm did not decrease below $0.69 \pm 0.02$ units. Therefore, under the influence of the bacteriophage, the young 24-hour biofilm was destroyed, but most of it (about $60 \%$ ) during the period of 32 hours was not subjected to lysis.

Under the influence of the bacteriophage, the number of microbial cells in biofilm during 4 hours of interaction did not decrease, but even increased by 1.8 times $(\mathrm{P}<0.05)$ (Table 1 ).

After 8 hours, their number decreased by 4.7 times $(\mathrm{P}<0.05)$ compared to the initial content. Starting almost on the 8 th hour of the bacteriophage's contact with microbial cells an active process of staphylococcal lysis took place. At the 24th hour from the time of infection with bacterial cells, the number of staphylococci per $1 \mathrm{ml}$ of extract from the biofilm was $1.9 \pm 0.1 \times 10^{3} \mathrm{CFU} / \mathrm{mL}$. Subsequent incubation up to the $32 \mathrm{nd}$ hour did not significantly reduce staphylococcal content in the biofilm.

The number of bacteriophages in the biofilm practically did not change during 8 hours of contact with microbial cells, although a ten- 
dency towards their growth was observed. By the 20th hour from the time of infection with staphylococci, the bacteriophage titre had increased by thirty times equaling $1.9 \pm 0.2 \times 10^{9} \mathrm{PFU} / \mathrm{mL}(\mathrm{P}<0.05)$. The increase in the number of bacteriophages in the biofilm coincided with the active lysis of staphylococci, since between the 20-28th hours their content was the lowest in the biofilm. After 32 hours of influence of the bacteriophage on the film-forming staphylococci, the titre of bacteriophages was $3.2 \pm 0.2 \times 10^{5} \mathrm{PFU} / \mathrm{mL}$. That is, we noted the regularity of gradual reduction of bacteriophage titre in the biofilm, which is related to the significant staphylococcal lysis. Thus, under the impact of bacteriophages on young 24-hour biofilms of S. aureus var. bovis, the full lysis of microbial cells did not occur within 32 hours of contact with the virus.

The time period during which a slight increase $(4.6 \pm 0.2 \%)$ occurred in the optical density of the dye from the biofilm was 8 hours (Fig. 2). At the 12th hour of interaction of the bacteriophage with the microbial cell, a decrease by $22.0 \pm 1.3 \%(\mathrm{P}<0.05)$ in the optical density of dye was observed, compared to the biofilm grown without the bacteriophage, and by $11.2 \pm 0.3 \%$ compared to the initial density. During the next hours of the impact of the bacteriophage, destruction of $77.5 \pm$ $1.4 \%(\mathrm{P}<0.05)$ of the biofilm occurred and at the 28th hour the density of the washed dye equaled $0.44 \pm 0.02$ units. Under the influence of the bacteriophage on mature 72-hour biofilms, their degradation was more intense compared with the young 24-hour biofilms - the amount of destroyed biofilm was on average 2 times $(\mathrm{P}<0.05)$ higher.

Table 1

Number of $S$. aureus variant bovis in a 24-hour biofilm under the action of bacteriophage $(x \pm S E, n=8)$

\begin{tabular}{lcc}
\hline $\begin{array}{c}\text { Time of bacteriophage } \\
\text { influence, hours }\end{array}$ & $\begin{array}{c}\text { Bacterial viable } \\
\text { count, CFU/mL }\end{array}$ & $\begin{array}{c}\text { Phage titre, } \\
\text { PFU/mL }\end{array}$ \\
\hline 0 (start) & $1.5 \pm 0.1 \times 10^{6}$ & $1.6 \pm 0.1 \times 10^{6}$ \\
4 & $2.7 \pm 0.2 \times 10^{6}$ & $1.8 \pm 0.2 \times 10^{6}$ \\
8 & $3.2 \pm 0.3 \times 10^{5 *}$ & $1.9 \pm 0.2 \times 10^{6}$ \\
12 & $8.1 \pm 0.7 \times 10^{4 *}$ & $1.1 \pm 0.1 \times 10^{7 *}$ \\
16 & $4.3 \pm 0.4 \times 10^{4 *}$ & $2.7 \pm 0.3 \times 10^{8 *}$ \\
20 & $2.3 \pm 0.2 \times 10^{4 *}$ & $1.9 \pm 0.2 \times 10^{9 * \Delta}$ \\
24 & $1.9 \pm 0.1 \times 10^{3 *}$ & $1.6 \pm 0.1 \times 10^{7 \Delta}$ \\
28 & $1.5 \pm 0.1 \times 10^{3 *}$ & $4.8 \pm 0.5 \times 10^{6 \Delta}$ \\
32 & $1.3 \pm 0.1 \times 10^{3 *}$ & $3.2 \pm 0.2 \times 10^{5 * \Delta}$ \\
\hline
\end{tabular}

Note: ${ }^{\#}$ - the biofilm was grown for 24 hours and then the bacteriophage was introduced; CFU - colony-forming unit; PFU - plaque-forming unit; * $-\mathrm{P}<0.05$ in comparison with the initial number, ${ }^{\Delta}-\mathrm{P}<0.05$ in comparison with the number of staphylococci.
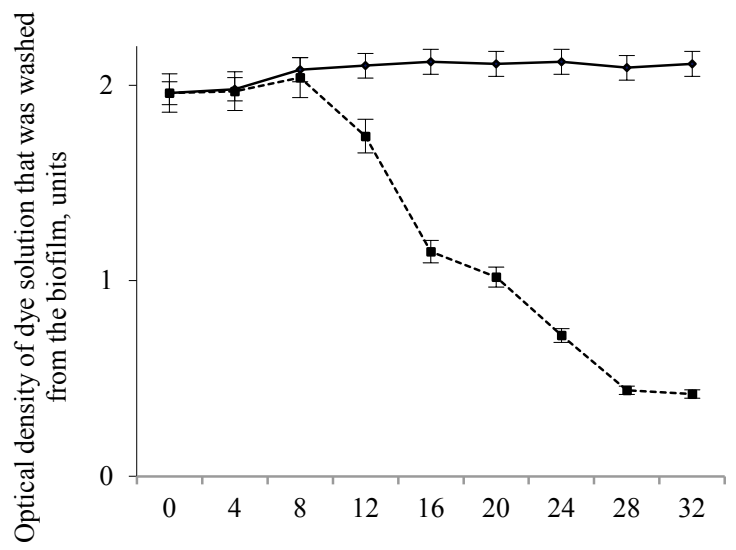

Exposure time of the bacteriophage to the biofilms, hours

Fig. 2. Influence of the bacteriophage on a 72-hour biofilm S. aureus variant bovis: solid line - optical density of dye solution from biofilms without influence of bacteriophage (control); dashed line-optical density of dye solution from biofilms under the influence of bacteriophage (experiment); data are shown as mean $\pm \mathrm{SD}$
During 4 hours of interaction of the bacteriophage and staphylococcal cells in biofilm, changes in the number of bacteria did not occur, and the number of phages increased by twenty times (Table 2).

\section{Table 2}

Number of $S$. aureus variant bovis in a 72-hour biofilm subject to the action of bacteriophage $(x \pm S E, n=8)$

\begin{tabular}{lcc}
\hline $\begin{array}{c}\text { Time of phage } \\
\text { influence, hours }\end{array}$ & $\begin{array}{c}\text { Bacterial viable } \\
\text { count, CFU/mL }\end{array}$ & $\begin{array}{c}\text { Phage titre, } \\
\text { PFU } / \mathrm{mL}\end{array}$ \\
\hline 0 (start) & $9.3 \pm 0.9 \times 10^{7}$ & $1.6 \pm 0.1 \times 10^{6 \Delta}$ \\
4 & $9.4 \pm 0.9 \times 10^{7}$ & $1.2 \pm 0.1 \times 10^{8 *}$ \\
8 & $5.2 \pm 0.5 \times 10^{6 *}$ & $1.1 \pm 0.2 \times 10^{9 *}$ \\
12 & $6.7 \pm 0.7 \times 10^{5 *}$ & $2.4 \pm 0.2 \times 10^{8 * \Delta}$ \\
16 & $4.4 \pm 0.4 \times 10^{3 *}$ & $3.7 \pm 0.4 \times 10^{7 * \Delta}$ \\
20 & $9.1 \pm 0.9 \times 10^{2 *}$ & $2.1 \pm 0.2 \times 10^{7 * \Delta}$ \\
24 & $2.2 \pm 0.2 \times 10^{2 *}$ & $1.8 \pm 0.2 \times 10^{6 \Delta}$ \\
28 & $1.0 \pm 0.1 \times 10^{2 *}$ & $3.5 \pm 0.4 \times 10^{3 * \Delta}$ \\
32 & 0 & $10^{1 *}$ \\
\hline
\end{tabular}

Note: ${ }^{\#}-$ the biofilm was grown for 72 hours and then the bacteriophage was introduced; $\mathrm{CFU}$ - colony-forming unit; $\mathrm{PFU}$ - plaque-forming unit; * $-\mathrm{P}<0.05$ in comparison with the initial number $;{ }^{\Delta}-\mathrm{P}<0.05$ in comparison with the number of staphylococci.

After 8 hours of contact of the virus and bacteria, the lysis process of microbial cells began and their number decreased by ten times $(\mathrm{P}<$ $0.05)$, and the number of bacteriophages increased to $1.1 \pm 0.2 \times 10^{9}$ $\mathrm{PFU} / \mathrm{mL}(\mathrm{P}<0.05)$. After 12 hours of exposure to the bacteriophage, the process of fading of staphylococci in the biofilm continued. At the same time, the bacteriophage content ceased to increase and their number was $2.4 \pm 0.2 \times 10^{8} \mathrm{PFU} / \mathrm{mL}$. During the next hours of interaction of bacteriophages and staphylococci in the biofilm, the lytic action of bacteriophages continued, and after 32 hours from the beginning of the phages' contact with the biofilm no bacterial cells were isolated.

\section{Discussion}

Bacteriophages can harmfully interact with bacteria that form biofilms at different stages of its formation: "before" formation, "during" maturation and "after" maturation (Wills et al., 2005; Kelly et al., 2012). Their potential to interact with biofilm bacteria at any of these stages depends on the amount of bacterial targets and the susceptibility of microorganisms to phage adsorption (Donlan, 2009). The lysis of microbial cells in a biofilm exposed to bacteriophages is possible only if the exopolysaccharide matrix is destroyed. This occurs when phages produce specific depolymerase enzymes that destroy a significant part of the matrix and make film-forming bacteria vulnerable (Azeredo et al., 2008; Fischetti, 2008; Vorobey et al., 2017).

The obtained data showed that the optical density of dye solution from the young biofilm (24-hour) of $S$. aureus var. bovis under the influence of reproduction of Phage SAvB14 bacteriophage decreased by $34.5 \pm 0.7 \%$ after 32 hours. This indicates that the matrix has constituents that are not lysed by enzymes of this bacteriophage. The variety of structural components of the biofilm matrix has been reported in a number of studies (Flemming \& Wingender, 2010; Hyman et al., 2013; Vorobey et al., 2017), which revealed $12.0 \%$ content of exopolysaccharides and about $15.0 \%$ nucleic acids in biofilms of $S$. aureus. It is also reported that active lysis of biofilm by phage depolymerases requires a specific susceptibility of bacterial cells to phage receptors (Weinbauer, 2004; Briandet et al., 2008; Hyman et al., 2013). We think that during the passive effect of bacteriophages on young 24-hour biofilms, pseudolizogenic infection of microbial cells occurs, as during 8 hours of interaction of the phage and staphylococcus, the biofilm was not destroyed, but even grew. This indicates that during this time, the bacteriophage infects film-forming cells of staphylococcus, but their lysis does not occur as a result of the development of pseudolysogeny: form of interaction of phage and microbial cell, in which the nucleic acid of the virus is present in the cell in an unstable, inactive state. In such cells, due to the intensity of their development, the phage does not have enough energy to initiate genetic expression for the lytic reaction (Abedon, 2009; Howard-Varona et al., 2017). Therefore, during this period, increase in biofilm occurs and, 
accordingly, increase in optical density of its dye solution. At the same time, the number of staphylococcal cells increased by 1.8 times within 4 hours of infection. In addition, exposure of the young biofilm to the bacteriophage for over 32 hours did not result in the total death of microbial cells, and the number of staphylococci was $1.3 \pm 0.1 \times 10^{3}$ $\mathrm{CFU} / \mathrm{mL}$ of rinsed extract. Therefore, the research has shown that mature 72-hour biofilm forms of staphylococci are more actively lysed under the influence of the bacteriophage than their young 24-hour biofilm forms.

Kasman et al. (2002) report that in order to inhibit fast-growing bacterial cells in vitro, a constant high concentration of bacteriophages equaling $10^{7}-10^{8} \mathrm{PFU} / \mathrm{mL}$ is needed. Probably, during an acute septic process, the use of phages will be less effective than during chronic sepsis, since the population of pathogenic bacteria would not completely destroyed, but maintained at a certain high level. A number of studies (Kelly et al., 2012) have shown that the effective removal of bacterial biofilm forms using a mixture of phages in the concentration of $10^{9} \mathrm{PFU} / \mathrm{mL}$ depended on the time of exposure, and at $37^{\circ} \mathrm{C}$, the greatest destruction of microbial cells occurred after 72 hours. Other researchers (Alves et al., 2014) by using the combined staphylococcal bacteriophage for the degradation of biofilm formed by $S$. aureus completely removed it in 48 hours at $37^{\circ} \mathrm{C}$. In laboratory conditions, staphylococcal bacteriophages such as ISP, Romulas and Remus in the concentration of $10^{9} \mathrm{PFU} / \mathrm{mL}$ reduced biofilms by $37.8 \%, 34.4 \%$ and $60.4 \%$, respectively, after 24 hours (Vandersteegen et al., 2013). Similar results were obtained in the studies (Gutieras et al., 2015) where a mixture of phages phil PLA-RODI and phil PLA-C1C was used against the formed biofilm of $S$. aureus. The phages reduced the number of microbial cells by $2 \log$ in the biofilm 8 hours after treatment at $37^{\circ} \mathrm{C}$ incubation.

Subclinical mastitis of cows in $90-95 \%$ of cases occurs in chronic form and the main pathogen $S$. aureus forms mature biofilms that influence the effectiveness of antibiotic therapy (Horiuk et al., 2019). In our studies, under the effect of Phage SAvB14 on 72-hour biofilms formed by S. aureus var. bovis, their degradation by $77.5 \pm 1.4 \%$ occurred during 32 hours at $37^{\circ} \mathrm{C}$. In this case, no viable microbial cells from the biofilm were isolated, and the bacteriophage titre was about $10^{1} \mathrm{PFU} / \mathrm{mL}$. In this case, we can state that the phages penetrated and reached staphylococcal cells throughout the entire biofilm layer and the bacteria were susceptible to this phage. That is, a passive impact on biofilms by phages occurred, in which lysis depended on the rate of absorption of the virus. Despite the fact that we obtained a rather effective bacteriophage action against the biofilm formed by $S$. aureus var. bovis in conditions in vitro, a number of authors (Hyman \& Abedon, 2010) report that the in situ process of biofilm lysis depends on many factors associated with the physiological state of the host. However, some researchers (Abedon, 2011; Gutieras et al., 2015; Lopetuso et al., 2019) agree unanimously that in practical application of bacteriophages, the concentration of phages should be at least $10^{8} \mathrm{PFU} / \mathrm{mL}$ for a certain time for passive biofilm lysis, since active processing by phages should provide a sufficient number of offspring to infect microbial cells and effect biofilm lysis.

Therefore, the results of laboratory studies indicate the prospect of efficient use of the specific staphylococcal bacteriophage Phage SAvB14, which we isolated for the destruction of biofilm formed by S. aureus var. bovis - from cows with mastitis.

\section{Conclusion}

Under the influence of staphylococcal bacteriophages on young 24hour biofilms of $S$. aureus var. bovis we observed decrease in the optical density of dye solution by $34.5 \pm 0.7 \%$ after 32 hours at $37^{\circ} \mathrm{C}$, compared with the initial density. Also, decrease from $1.5 \pm 0.3 \times 10^{6}$ to $1.3 \pm$ $0.2 \times 10^{3} \mathrm{CFU} / \mathrm{mL}$ of the rinsed extract was observed for the number of S. aureus cells in biofilm after 32 hours of the experiment. This indicates that microbial cells of young biofilms are not susceptible to complete lysis at the impact of even a specific bacteriophage. At the same time, at the influence of the bacteriophage on mature 72-hour biofilms, $77.5 \pm$ $1.4 \%$ degradation in the biofilms was observed after 32 hours at $37^{\circ} \mathrm{C}$. At the same time, no viable cells of $S$. aureus were isolated from the biofilm. This indicates the high lytic activity of the bacteriophage to- wards mature biofilm bacteria and the possibility of its use in treating chronic staphylococcal infections caused by S. aureus var. bovis.

\section{References}

Abedon, S. T. (2009). Kinetics of phage-mediated biocontrol of bacteria. Foodborne Pathogens and Disease, 6(7), 807-815.

Abedon, S. T. (2011). Lysis from without. Bacteriophage, 1(1), 46-49.

Alves, D. R., Gaudion, A., Bean, J. E., Esteban, P. P., Arnot, T. C., Harper, D. R., Jenkins, A. T. A. (2014). Combined use of bacteriophage K and a novel bacteriophage to reduce Staphylococcus aureus biofilm formation. Applied and Environmental Microbiology, 80(21), 6694-6703.

Azeredo, J., \& Sutherland, I. W. (2008). The use of phages for the removal of infectious biofilms. Current Pharmaceutical Biotechnology, 9(4), 261-266.

Bahamondez-Canas, T. F., Zhang, H., Tewes, F., Leal, J., \& Smyth, H. D. (2018). PEGylation of tobramycin improves mucus penetration and antimicrobial activity against Pseudomonas aeruginosa biofilms in vitro. Molecular Pharmaceutics, 15(4), 1643-1652.

Briandet, R., Lacroix-Gueu, P., Renault, M., Lecart, S., Meylheuc, T., Bidnenko, E., \& Fontaine-Aupart, M. P. (2008). Fluorescence correlation spectroscopy to study diffusion and reaction of bacteriophages inside biofilms. Applied and Environmental Microbiology, 74(7), 2135-2143.

Cabrera, C. E., Gomez, R. F., Zuñiga, A. E., Corral, R. H., López, B. \& Chávez, M. (2011). Epidemiology of nosocomial bacteria resistant to antimicrobials. Colombia Medica, 42(1), 117-125.

Dias, R. S., Eller, M. R., Duarte, V. S., Pereira, A. L., Silva, C. C., Mantovani, H. C., Oliveira, L. L., Silva, E. de A. M., \& Paula, S. O. (2013). Use of phages against antibiotic-resistant Staphylococcus aureus isolated from bovine. Journal of Animal Science, 91, 3930-3939.

Donlan, R. M. (2009). Preventing biofilms of clinically relevant organisms using bacteriophage. Trends in Microbiology, 17(2), 66-72.

Felipe, V., Breser, M. L., Bohl, L. P., da Silva, E. R., Morgante, C. A., Correa, S. G., \& Porporatto, C. (2019). Chitosan disrupts biofilm formation and promotes biofilm eradication in Staphylococcus species isolated from bovine mastitis. International Journal of Biological Macromolecules, 126, 60-67.

Fischetti, V. A. (2008). Bacteriophage lysins as effective antibacterials. Current Opinion in Microbiology, 11(5), 393-400.

Flemming, H. C., \& Wingender, J. (2010). The biofilm matrix. Nature Reviews Microbiology, 8(9), 623-633.

Gutierrez, D., Vandenheuvel, D., Martínez, B., Rodríguez, A., Lavigne, R., \& García, P. (2015). Two phages, phiIPLA-RODI and phiIPLA-C1C, lyse mono- and dual-species staphylococcal biofilms. Applied and Environmental Microbiology, 81(10), 3336-3348.

Horiuk, Y. V. (2018). Fagotherapy of cows mastitis as an alternative to antibiotics in the system of obtaining environmentally safe milk. Scientific Messenger of Lviv National University of Veterinary Medicine and Biotechnologies, 20(88), 42-47.

Horiuk, Y. V., Kukhtyn, M. D., Strayskyy, Y. S., Havrylianchyk, R. Y., Horiuk, V. V., \& Fotina, H. A. (2018). Comparison of the minimum bactericidal concentration of antibiotics on planktonic and biofilm forms of Staphylococcus aureus: Mastitis causative agents. Research Journal of Pharmaceutical, Biological and Chemical Sciences, 9(6), 616-622.

Horiuk, Y., Kukhtyn, M., Kovalenko, V., Kornienko, L., Horiuk, V., \& Liniichuk, N. (2019). Biofilm formation in bovine mastitis pathogens and the effect on them of antimicrobial drugs. Independent Journal of Management and Production, 10(7), 897-910

Howard-Varona, C., Hargreaves, K. R., Abedon, S. T., \& Sullivan, M. B. (2017) Lysogeny in nature: Mechanisms, impact and ecology of temperate phages. The ISME Journal, 11(7), 1511-1520.

Hurlow, J., Couch, K., Laforet, K., Bolton, L., Metcalf, D., \& Bowler, P. (2015). Clinical biofilms: A challenging frontier in wound care. Advances in Wound Care, 4(5), 295-301.

Hyman, P., \& Abedon, S. T. (2010). Bacteriophage host range and bacterial resistance. Advances in Applied Microbiology, 70, 217-248.

Hymes, S. R., Randis, T. M., Sun, T. Y., \& Ratner, A. J. (2013). DNAse inhibits Gardnerella vaginalis biofilms in vitro and in vivo. The Journal of Infectious Diseases, 207(10), 1491-1497.

Iglesias, Y. D., Wilms, T., Vanbever, R., \& Van Bambeke, F. (2019). Activity of antibiotics against Staphylococcus aureus in an in vitro model of biofilms in the context of cystic fibrosis: Influence of the culture medium. Antimicrobial Agents and Chemotherapy, 63(7), e00602-19.

Kasman, L. M., Kasman, A., Westwater, C., Dolan, J., Schmidt, M. G., \& Norris, J.S. (2002). Overcoming the phage replication threshold: A mathematical model with implications for phage therapy. Journal of Virology, 76(11), 5557-5564.

Kelly, D., McAuliffe, O., Ross, R. P., \& Coffey, A. (2012). Prevention of Staphylococcus aureus biofilm formation and reduction in established biofilm den- 
sity using a combination of phage $\mathrm{K}$ and modified derivatives. Letters in $\mathrm{Ap}$ plied Microbiology, 54(4), 286-291.

Kukhtyn, M., Berhilevych, O., Kravcheniuk, K., Shynkaruk, O., Horiuk, Y., \& Semaniuk, N. (2017). Formation of biofilms on dairy equipment and the influence of disinfectants on them. Eastern-European Journal of Enterprise Technologies, 89, 26-33.

Latka, A., Maciejewska, B., Majkowska-Skrobek, G., Briers, Y., \& Drulis-Kawa, Z (2017). Bacteriophage-encoded virion-associated enzymes to overcome the carbohydrate barriers during the infection process. Applied Microbiology and Biotechnology, 101(8), 3103-3119.

Lopetuso, L., Giorgio, M., Saviano, A., Scaldaferri, F., Gasbarrini, A., \& Cammarota, G. (2019). Bacteriocins and bacteriophages: Therapeutic weapons for gastrointestinal diseases? International Journal of Molecular Sciences, 20(1), $183-195$.

Mah, T. F. C., \& O'Toole, G. A. (2001). Mechanisms of biofilm resistance to antimicrobial agents. Trends in Microbiology, 9(1), 34-39.

Milho, C., Silva, M. D., Sillankorva, S., \& Harper, D. R. (2019). Biofilm applications of bacteriophages. In: Harper, D., Abedon, S., Burrowes, B., McConville, M. (eds.). Bacteriophages. Springer Nature Switzerland AG, Cham.

Morris, J., Kelly, N., Elliott, L., Grant, A., Wilkinson, M., Hazratwala, K., \& McEwen, P. (2018). Evaluation of bacteriophage anti-biofilm activity for potential control of orthopedic implant-related infections caused by Staphylococcus aureus. Surgical Infections, 20(1), 16-24.

Parasion, S., Kwiatek, M., Gryko, R., Mizak, L., \& Malm, A. (2014). Bacteriophages as an alternative strategy for fighting biofilm development. Polish Journal of Microbiology, 63(2), 137-145.

Siala, W., Rodriguez-Villalobos, H., Fernandes, P., Tulkens, P. M., \& Van Bambeke, F. (2018). Activities of combinations of antistaphylococcal antibiotics with fusidic acid against staphylococcal biofilms in in vitro static and dynamic models. Antimicrobial Agents and Chemotherapy, 62(7), e00598-18.

Stepanović, S., Vuković, D., Dakić, I., Savić, B., \& Švabić-Vlahović, M. (2000) A modified microtiter-plate test for quantification of staphylococcal biofilm formation. Journal of Microbiological Methods, 40(2), 175-179.

Stewart, P. S., \& Franklin, M. J. (2008). Physiological heterogeneity in biofilms. Nature Reviews Microbiology, 6(3), 199.

Svircev, A., Roach, D., \& Castle, A. (2018). Framing the future with bacteriophages in agriculture. Viruses, 10(5), 218.

Tkhilaishvili, T., Lombardi, L., Klatt, A. B., Trampuz, A., \& Di Luca, M. (2018). Bacteriophage $\mathrm{Sb}-1$ enhances antibiotic activity against biofilm, degrades exopolysaccharide matrix and targets persisters of Staphylococcus aureus. International Journal of Antimicrobial Agents, 52(6), 842-853.

Vandersteegen, K., Kropinski, A. M., Nash, J. H., Noben, J. P., Hermans, K., \& Lavigne, R. (2013). Romulus and Remus, two phage isolates representing a distinct clade within the Twortlikevirus genus, display suitable properties for phage therapy applications. Journal of Virology, 87(6), 3237-3247.

Vorobey, E. S., Voronkova, O. S., \& Vinnikov, A. I. (2017). Correction of vaginal dysbiosis in mice caused by a film-forming strain Staphylococcus aureus, using bacteriophages and probiotics. Regulatory Mechanisms in Biosystems, $8(2), 252-258$

Weinbauer, M. G. (2004). Ecology of prokaryotic viruses. FEMS Microbiology Reviews, 28(2), 127-181.

Wills, Q. F., Kerrigan, C., \& Soothill, J. S. (2005). Experimental bacteriophage protection against Staphylococcus aureus abscesses in a rabbit model. Antimicrobial Agents and Chemotherapy. 49(3), 1220-1221.

Zimmerli, W., \& Sendi, P. (2019). Role of rifampin against staphylococcal biofilm infections in vitro, in animal models, and in orthopedic-device-related infections. Antimicrobial Agents and Chemotherapy, 63(2), e01746-18. 